\title{
Pemodelan Jumlah Kematian Ibu Nifas di Karesidenan Pekalongan Provinsi Jawa Tengah Tahun 2017 Menggunakan Regresi Zero-Inflated Poisson Inverse Gaussian
}

\author{
Herni Anggi Riski Rahayuning ${ }^{(1)}$ dan Purhadi $^{(2)}$ \\ Departemen Statistika, Fakultas Sains dan Analitika Data (FSAD) \\ Institut Teknologi Sepuluh Nopember (ITS) \\ Jl. Arief Rahman Hakim, Surabaya 60111 Indonesia \\ e-mail: ${ }^{(1)}$ hernianggi@gmail.com dan ${ }^{(2)}$ purhadi@statistika.its.ac.id
}

\begin{abstract}
Abstrak - Angka Kematian Ibu (AKI) adalah rasio kematian ibu pada masa kehamilan, persalinan, dan nifas yang disebabkan oleh kehamilan, persalinan, dan nifas atau pengelolaannya tetapi bukan karena sebab-sebab lain seperti kecelakaan atau terjatuh di setiap 100.000 kelahiran hidup. Karesidenan Pekalongan merupakan karesidenan yang memiliki AKI tertinggi di Provinsi Jawa Tengah yang sebagian besar kematian disebabkan oleh ibu nifas. Regresi Zero-Inflated Poisson Inverse Gaussian (ZIPIG) merupakan model yang dapat menangani kasus pelanggaran asumsi ekuidispersi yang disebabkan oleh banyaknya nilai nol (extra zeros) pada variabel respon. Pada penelitian ini digunakan data jumlah kematian ibu nifas menurut kecamatan di Karesidenan Pekalongan Provinsi Jawa Tengah tahun 2017 sebagai variabel respon dan enam variabel lainnya sebagai variabel prediktor. Data kematian ibu nifas tersebut memiliki nilai nol sebesar $60,44 \%$, varians sebesar 0,91 dan mean sebesar 0,67 yang menandakan bahwa data mengalami overdispersi. Faktor yang berpengaruh signifkan terhadap jumlah kematian ibu nifas dari pemodelan menggunakan regresi ZIPIG yaitu persentase ibu nifas yang mendapatkan vitamin $A\left(X_{1}\right)$ dan persentase persalinan ibu hamil yang persalinannya ditolong oleh tenaga kesehatan $\left(\mathbf{X}_{3}\right)$.
\end{abstract}

Kata Kunci - Angka Kematian Ibu, Extra Zeros, Nifas, Overdispersi, Regresi Zero-Inflated Poisson Inverse Gaussian (ZIPIG)

\section{PENDAHULUAN}

A ngka Kematian Ibu (AKI) adalah rasio kematian ibu pada masa kehamilan, persalinan, dan nifas yang disebabkan oleh kehamilan, persalinan, dan nifas atau pengelolaannya tetapi bukan karena sebab-sebab lain seperti kecelakaan atau terjatuh di setiap 100.000 kelahiran hidup [1]. Angka Kematian Ibu (AKI) menjadi salah satu indikator penting dari derajat kesehatan masyarakat. AKI mencerminkan risiko yang dihadapi ibu-ibu selama kehamilan sampai dengan paska persalinan. Tingginya angka kematian ibu menunjukkan keadaan sosial ekonomi yang rendah dan fasilitas pelayanan kesehatan termasuk pelayanan prenatal dan obstetri yang rendah pula [2]. Dalam Sasaran Pembangunan Berkelanjutan atau SDGs (Sustainable Development Goals), penurunan AKI merupakan salah satu tujuan global yang tertuang dalam tujuan ketiga pada SDGs yaitu menjamin kehidupan yang sehat dan meningkatkan kesejahteraan bagi seluruh penduduk di semua usia. Dengan demikian, kematian ibu merupakan salah satu indikator penting dalam pembangunan di bidang kesehatan suatu negara dan khususnya bagi pencapaian SDGs negara tersebut.

Indonesia masih tergolong tinggi jika dibandingkan dengan AKI di dunia. Indonesia menduduki peringkat kedua sebagai negara dengan AKI terbanyak di ASEAN. AKI di Indonesia sebesar 305 kematian per 100.000 kelahiran hidup, sedangkan AKI di dunia sebesar 216 kematian per 100.000 kelahiran hidup [3]. Angka tersebut masih di atas Angka Kematian Ibu di negara-negara ASEAN yang memiliki AKI sebesar 197 per 100 ribu kelahiran hidup [4]. Provinsi Jawa Tengah menjadi provinsi yang memiliki angka kematian ibu tertinggi di Indonesia pada tahun 2017, yaitu sebesar 68,7 per 100.000 kelahiran hidup. Berdasarkan waktu terjadinya, pada tahun 2017 sebesar $60 \%$ kematian ibu di Jawa Tengah terjadi pada waktu nifas, $26,23 \%$ pada waktu hamil, dan $13,68 \%$ pada waktu persalinan [5]. Karesidenan Pekalongan merupakan karesidenan yang memiliki AKI tertinggi di Provinsi Jawa Tengah yang sebagian besar kematian disebabkan oleh ibu nifas yaitu sebesar 171 kasus pada tahun 2016, 114 kasus pada tahun 2017 dan menduduki peringkat kedua setelah Karesidenan Semarang yaitu sebesar 99 kasus pada tahun 2018.

Distribusi Poisson merupakan distribusi probabilitas acak yang menyatakan banyaknya sukses yang terjadi dalam selang waktu tertentu sehingga nilai yang mungkin dari variabel respon adalah bilangan cacah. Data cacahan sering kali mengandung nilai nol (extra zeros) yang dapat menyebabkan overdispersi. Pemodelan yang digunakan untuk mengatasi masalah overdispersi menggunakan perpaduan antara distribusi Poisson dengan distribusi lain yang diskrit maupun kontinyu (mixed poisson distribution). Beberapa mixed poisson distribution yang telah dikembangkan yaitu Zero-Inflated Poisson (ZIP), Generalized Poisson, Negative Binomial Poisson, dan Poisson Inverse Gaussian. Famoye dan Singh memperkirakan proporsi data bernilai nol yang sesuai untuk model ZIP adalah sebesar 63,7\%. Model Zero-Inflated Poisson Inverse Gaussian Regression (ZIPIGR) merupakan metode pengembangan yang menggabungkan model ZeroInflated (ZI) yang menangani extra zeros dan Poisson Inverse Gaussian (PIG) yang menangani kasus pelanggaran asumsi ekuidispersi. Data jumlah kematian ibu nifas di Karesidenan Pekalongan merupakan salah satu contoh data cacah yang mengikuti distribusi Poisson dikarenakan jumlah kejadiannya selalu berupa bilangan cacah. Data tersebut memiliki nilai nol sebesar $60,44 \%$, dan nilai mean yang kurang dari varians yaitu sebesar 0,67 sedangkan varians sebesar 0,91. Nilai tersebut mengindikasikan terjadinya kasus overdispersi.

Data dalam penelitian ini mengandung extra zeros yang dapat dilakukan pemodelan dengan menggunakan ZeroInflated, tetapi data extra zeros tersebut menyebabkan overdispersi, pelanggaran asumsi ekuidispersi ini dapat diatasi dengan distribusi Poisson Inverse Gaussian. Maka dari itu untuk menangani hal tersebut digunakan model Zero-Inflated Poisson Inverse Gaussian Regression (ZIPIGR) untuk mengetahui faktor-faktor apa saja yang berpengaruh terhadap jumlah kematian ibu nifas di Karesidenan Pekalongan Provinsi 
Jawa Tengah Tahun 2017, dikarenakan Karesidenan Pekalongan memiliki jumlah kematian ibu nifas tertinggi di Jawa Tengah pada tahun 2017. Penelitian ini diharapkan mampu menjadi bahan pertimbangan bagi Dinas Kesehatan Provinsi Jawa Tengah dalam menentukan kebijakan atau program terkait penanganan kematian ibu nifas di Provinsi Jawa Tengah. Sehingga diharapkan nantinya jumlah kematian ibu nifas akan mengalami penurunan dan nilainya semakin mendekati target RPJMN dan SDGs.

\section{TINJAUAN PUSTAKA}

\section{A. Statistika Deskriptif}

Statistika deskriptif adalah metode-metode yang berkaitan dengan pengumpulan dan penyajian suatu data sehingga memberikan informasi yang berguna [6]. Pada Penelitian ini, statistika deskriptif yang digunakan adalah mean, varians, nilai maksimum, dan minimum. Rumus nilai mean dapat dituliskan pada Persamaan (1).

$$
\bar{X}=\frac{\sum_{i=1}^{n} X_{i}}{n}=\frac{X_{1}+X_{2}+\ldots+X_{n}}{n}
$$

dimana, $\bar{X}$ adalah rata-rata (mean), $i: 1,2, \ldots, n$, dan $n$ adalah banyaknya data. Sedangkan rumus varians dapat dituliskan pada Persamaan (2).

$$
s^{2}=\frac{\sum_{i=1}^{n}\left(X_{i}-\bar{X}\right)^{2}}{n-1}
$$

dimana $s^{2}$ adalah varians dari sampel data, $n$ adalah banyaknya data, dan $\bar{X}$ adalah rata-rata (mean).

\section{B. Uji Korelasi}

Koefisien korelasi adalah nilai yang digunakan untuk mencari keeratan hubungan antara dua variabel atau lebih [6]. Korelasi yang digunakan untuk menghitung korelasi antar variabel kontinyu atau diskrit yaitu korelasi Pearson sebagaimana disajikan pada Persamaan (3).

$$
\rho_{x, y}=\frac{\operatorname{cov}(X, Y)}{\sqrt{\operatorname{var}(X) \operatorname{var}(Y)}}
$$

Uji korelasi memiliki hipotesis sebagai berikut. Hipotesis :

$\mathrm{H}_{0}: \rho_{x, y}=0$ (Tidak ada hubungan antar kedua variabel)

$\mathrm{H}_{1}: \rho_{x, y} \neq 0$ (Terdapat hubungan antar kedua variabel)

Statistik uji :

$$
\begin{gathered}
t=\frac{r_{x, y} \sqrt{n-2}}{\sqrt{1-r^{2}}} \\
\operatorname{dimana} r_{x, y}=\frac{\sum_{i=1}^{n}\left(x_{i}-\bar{x}\right)\left(y_{i}-\bar{y}\right)}{\sqrt{\sum_{i=1}^{n}\left(x_{i}-\bar{x}\right)^{2} \sum_{i=1}^{n}\left(y_{i}-\bar{y}\right)^{2}}}
\end{gathered}
$$

Keputusan yang didapatkan akan Tolak $\mathrm{H}_{0}$ jika nilai $\left|t_{\text {hitung }}\right|>t_{\alpha / 2 ;(\mathrm{n}-2)}$ atau $p$-value $>\alpha$.

\section{Multikolinearitas}

Asumsi yang harus dipenuhi dalam analisis regresi yang menggunakan lebih dari satu variabel prediktor adalah tidak adanya gejala multikolinearitas atau antar variabel prediktor tidak saling berhubungan. Adanya multikolinearitas dalam model regresi yang dihasilkan memiliki standart error yang besar dengan signifikansi yang kecil. Multikolinearitas juga dapat mengakibatkan pengujian secara parsial menjadi tidak signifikan meskipun pengujian secara serentak memberikan hasil yang signifikan. Salah satu cara untuk mendeteksi adanya gejala multikolinearitas adalah dengan melihat nilai Variance Inflation Factor (VIF) [7]. Multikolinearitas terjadi apabila nilai VIF lebih dari 10. Rumus VIF dapat dituliskan pada Persamaan (5).

$$
V I F_{j}=\frac{1}{1-R_{j}^{2}}
$$

$\operatorname{dimana} R_{j}{ }^{2}=\frac{\sum_{i=1}^{n}\left(\hat{x}_{j i}-\bar{x}\right)^{2}}{\sum_{i=1}^{n}\left(x_{j i}-\bar{x}\right)^{2}}$.

\section{Ekuidispersi}

Asumsi yang harus terpenuhi dalam regresi Poisson yaitu nilai mean dan varians dari variabel respon harus bernilai sama (equidispersion). Namun pada kenyataannya sering kali ditemui kasus ketika varians dari variabel respon lebih besar dari nilai rata-ratanya atau disebut overdispersi. Overdispersi muncul ketika terjadi pelanggaran pada asumsi distribusi data, misal ketika data dikelompokkan sehingga melanggar asumsi observasi kebebasan likelihood [8]. Salah satu cara untuk mendeteksi keberadaan overdispersi adalah melihat nilai The Variance Test (VT). Rumus VT dapat dituliskan pada Persamaan (6).

$$
V T=\sum_{i=1}^{n} \frac{\left(y_{i}-\bar{y}\right)^{2}}{\bar{y}}=(n-1) \frac{s^{2}}{\bar{y}},
$$

Apabila nilai indeks dispersi $<1$ maka terjadi underdispersi, sedangkan apabila nilai indeks dispersi $>1$ maka terjadi overdispersi [9]. Uji statistik yang digunakan untuk mendeteksi overdispersi dapat dicari menggunakan package AER pada software $R$. Uji ini mengikuti distribusi Poisson yang mana nilai varians sama dengan nilai rata-rata dengan hipotesis sebagai berikut.

Hipotesis :

$$
\begin{array}{ll}
\mathrm{H}_{0} & : \operatorname{Var}(\mathrm{Y})=\mu \\
\mathrm{H}_{1} & : \operatorname{Var}(\mathrm{Y})=\mu+\mathrm{a} \cdot \mathrm{g}(.)
\end{array}
$$

dimana $g($.$) merupakan suatu fungsi tertentu. Nilai a$ merupakan parameter ekquidispersi, apabila nilai $a=0$ maka terjadi ekuidispersi, sedangkan apabila a>0 maka terjadi overdispersi.

Statistik uji :

$$
T=\frac{1}{2} \sum_{i=1}^{n}\left\{\left(y_{i}-\widehat{\mu}_{i}\right)^{2}-Y_{i}\right\}
$$

Keputusan yang didapatkan akan Tolak $\mathrm{H}_{0}$ jika $|T|>Z_{\left(\frac{\alpha}{2}\right)}$, dimana $\alpha$ adalah tingkat signifikansi.

\section{E. Regresi Zero-Inflated Poisson Inverse Gaussian}

Distrbusi poisson inverse Gaussian (PIG) merupakan salah satu pengembangan dari distribusi Poisson yang merupakan 
gabungan dari distribusi Poisson dengan distribusi Inverse Gaussian (IG). Sedangkan distribusi Zero-Inflated Poisson Inverse Gaussian (ZIPIG) merupakan gabungan dari distribusi zero-inflated poisson dengan distribusi IG. Fungsi kepadatan peluang $Y \sim \operatorname{ZIPIG}(\lambda, \tau, p)$ dapat dituliskan pada Persamaan (8).

$$
P\left(\begin{array}{l}
Y=y \mid \\
\lambda, \tau, p
\end{array}\right)=\left\{\begin{array}{l}
p+(1-p) e^{\frac{1}{\tau}}\left(\frac{2}{\pi \tau}\right)^{\frac{1}{2}}(2 \lambda \tau+1) \frac{1}{4}\left(\frac{\pi}{2\left(\frac{1}{\tau} \sqrt{(2 \lambda \tau+1)}\right)}\right)^{\frac{1}{2}} \\
\exp \left(-\frac{1}{\tau} \sqrt{(2 \lambda \tau+1)}\right) ; y=0 \\
(1-p) \frac{\lambda^{y} e^{\frac{1}{\tau}}}{y !}\left(\frac{2}{\pi \tau}\right)^{\frac{1}{2}}(2 \lambda \tau+1)^{-\frac{1}{2}} \\
\left(\frac{\left.\pi-\frac{1}{2}\right)}{2\left(\frac{1}{\tau} \sqrt{(2 \lambda \tau+1)}\right)}\right)^{y-\frac{1}{2}} \exp \left(-\frac{1}{\tau} \sqrt{(2 \lambda \tau+1)}\right) ; y=1,2,3, \ldots
\end{array}\right.
$$

Salah satu model regresi yang dapat digunakan untuk mengatasi jika terjadi kasus overdispersi pada data adalah regresi Zero-Inflated Poisson Inverse Gaussian (ZIPIG). Distribusi Zero-Inflated Poisson Inverse Gaussian (ZIPIG) merupakan salah satu dari mixed poisson distribution yaitu distribusi Poisson Inverse Gaussian (PIG) dengan distribusi zero-inflated (ZI). Distribusi PIG terdiri dari dau parameter yaitu $\lambda$ (rata-rata) dan $\tau$ (parameter dispersi), sedangkan distribusi ZI memiliki satu parameter yaitu $p$ (parameter zero inflation), sehingga pada distribusi ZIPIG terdiri dari tiga parameter yaitu $\lambda$, $\tau$, dan $p$. Jika terdapat variabel respon $Y \sim$ $\operatorname{ZIPIG}(\lambda, \tau, p)$, maka model ZIPIG dibagi menjadi dua komponen model yaitu data diskret untuk $\lambda$ dan model zeroinflated. Model untuk data diskret $\lambda$ dapat dituliskan pada Persamaan (9).

$$
\begin{aligned}
E(Y) & =\lambda \\
\lambda & =\exp \left(\boldsymbol{x}^{T} \boldsymbol{\beta}\right) \\
\ln (\lambda) & =\boldsymbol{x}^{T} \boldsymbol{\beta}
\end{aligned}
$$

Model zero-inflated dituliskan pada Persamaan (10).

$$
\operatorname{logit}(p)=\ln \left(\frac{p}{(1-p)}\right)=-\gamma \boldsymbol{x}^{T} \boldsymbol{\beta}
$$

dimana state $p$ dan 1- $p$ dituliskan pada Persamaan (11).

$$
p=\frac{\exp \left(-\gamma \boldsymbol{x}^{T} \boldsymbol{\beta}\right)}{1+\exp \left(-\gamma \boldsymbol{x}^{T} \boldsymbol{\beta}\right)} \text { dan }(1-p)=\frac{1}{1+\exp \left(-\gamma \boldsymbol{x}^{T} \boldsymbol{\beta}\right)} .
$$

Fungsi probabilitas dari model ZIPIGR dapat dituliskan pada Persamaan (12).

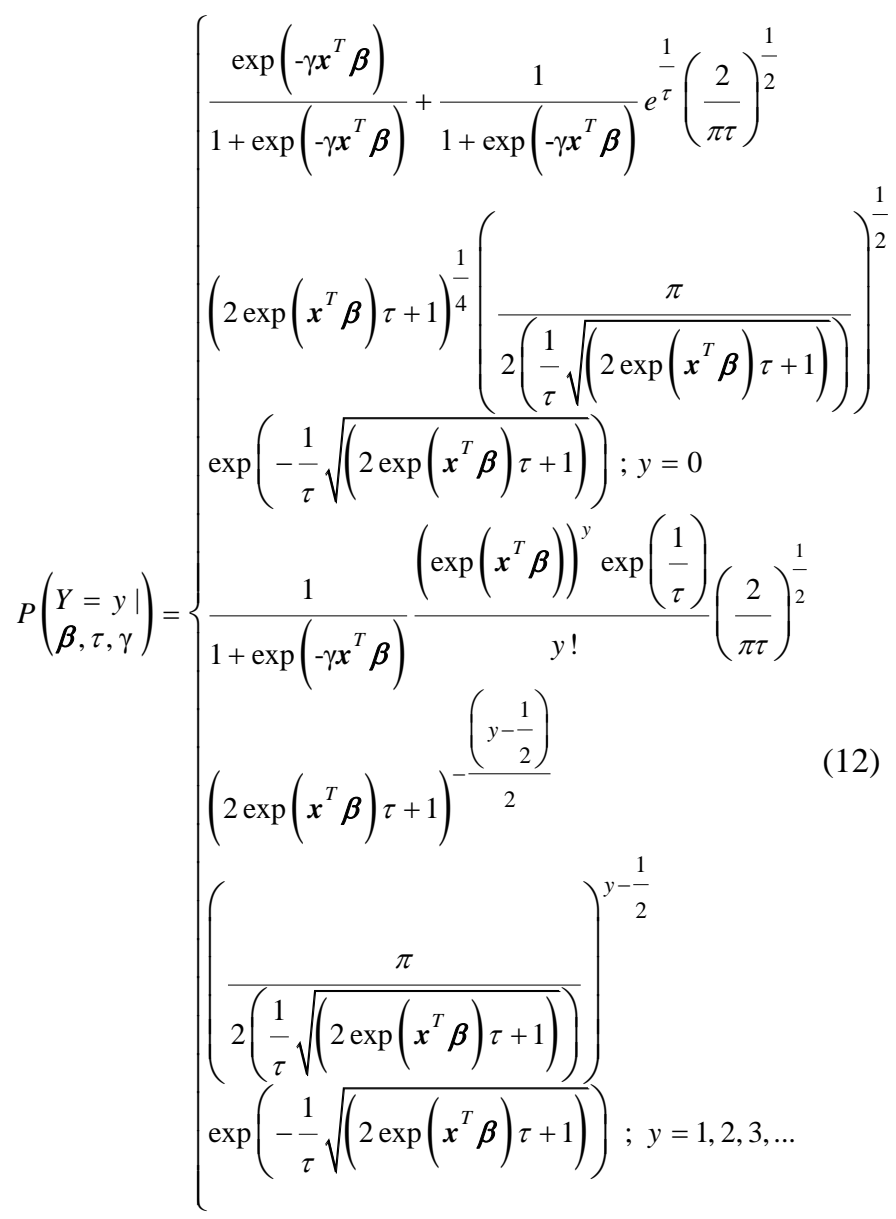

\section{F. Estimasi Parameter}

Estimasi parameter regresi ZIPIG dapat dilakukan dengan menggunakan metode Maximum Likelihood Estimation (MLE). Langkah pertama dalam estimasi parameter metode MLE yaitu dengan menentukan fungsi likelihood dari distribusi ZIPIG. Fungsi likelihoodnya dapat dituliskan pada Persamaan (13).

$L(\boldsymbol{\beta} ; \tau ; \gamma)=\left(\prod_{\substack{i=1 \\ y_{i}=0}}^{n} P\left(Y_{i}=y_{i} \mid \boldsymbol{x}_{i} ; \boldsymbol{\beta} ; \tau ; \gamma\right)\right)\left(\prod_{\substack{i=1 \\ y_{i}>0}}^{n} P\left(Y_{i}=y_{i} \mid \boldsymbol{x}_{i} ; \boldsymbol{\beta} ; \tau ; \gamma\right)\right.$

$L(\boldsymbol{\beta} ; \tau ; \gamma)=\left(L_{1}(\boldsymbol{\beta} ; \tau ; \gamma)\right)\left(L_{2}(\boldsymbol{\beta} ; \tau ; \gamma)\right)$

dimana

$$
\begin{aligned}
L_{1}(\boldsymbol{\beta} ; \tau ; \gamma) & =\prod_{\substack{i=1 \\
y_{i}=0}}^{n} \frac{1}{1+\exp \left(-\gamma \boldsymbol{x}_{i}{ }^{T} \boldsymbol{\beta}\right)}\left(\exp \left(-\gamma \boldsymbol{x}_{i}^{T} \boldsymbol{\beta}\right)\right. \\
& \left.+\exp \left(\frac{1}{\tau}-\frac{1}{\tau} \sqrt{2 \tau \exp \left(\boldsymbol{x}_{i}^{T} \boldsymbol{\beta}\right)+1}\right)\right)
\end{aligned}
$$

dan

$$
\begin{aligned}
L_{2}(\boldsymbol{\beta} ; \tau ; \gamma)=\prod_{\substack{i=1 \\
y_{i}>0}}^{n}\left\{\left(\frac{1}{1+\exp \left(-\gamma \boldsymbol{x}_{i}^{T} \boldsymbol{\beta}\right)}\right)\left(\frac{\left(\exp \left(\boldsymbol{x}_{i}^{T} \boldsymbol{\beta}\right)\right)^{y_{i}} \exp \left(\frac{1}{\tau}\right)}{y_{i} !}\right)\right. \\
\\
\qquad\left(\frac{2}{\pi \tau}\right)^{-y_{i}+1}\left(2 \tau \exp \left(\boldsymbol{x}_{i}^{T} \boldsymbol{\beta}\right)+1\right)^{-y_{i}+\frac{1}{2}} \\
\left.\exp \left(-\frac{1}{\tau} \sqrt{\left(2 \tau \exp \left(\boldsymbol{x}_{i}^{T} \boldsymbol{\beta}\right)+1\right)}\right)\right\}
\end{aligned}
$$


Apabila persamaan di atas merupakan persamaan implisit, sehingga untuk mendapatkan estimasi dari parameter dapat dilakukan dengan menggunakan Fisher Scoring Algorithm dapat dituliskan pada Persamaan (16).

$$
\hat{\boldsymbol{\theta}}_{(r+1)}=\hat{\boldsymbol{\theta}}_{(r)}+\mathbf{I}^{-1}\left(\hat{\boldsymbol{\theta}}_{(\mathrm{m})}\right) \mathbf{D}\left(\hat{\boldsymbol{\theta}}_{(\mathrm{m})}\right)
$$

dimana

$$
\begin{aligned}
& \widehat{\boldsymbol{\theta}}=\left(\hat{\boldsymbol{\beta}}^{T}, \widehat{\tau}, \widehat{\gamma}\right)^{T} \\
& \mathbf{D} \widehat{\boldsymbol{\theta}}=\left(\frac{\partial l}{\partial \hat{\gamma}}, \frac{\partial l}{\partial \hat{\tau}}, \frac{\partial l}{\partial \widehat{\boldsymbol{\beta}}^{T}}\right)^{T} \\
& \mathbf{I}\left(\hat{\boldsymbol{\theta}}_{(m)}\right)=-E\left[\mathbf{H}\left(\hat{\boldsymbol{\theta}}_{(m)}\right)\right] \\
& \mathbf{H}\left(\hat{\boldsymbol{\theta}}_{(m)}\right)_{(k+1)(k+1)}=\left[\begin{array}{ccc}
\frac{\partial^{2} l}{\partial \hat{\gamma}^{2}} & \frac{\partial^{2} l}{\partial \hat{\gamma} \partial \hat{\tau}} & \frac{\partial^{2} l}{\partial \hat{\gamma} \partial \hat{\boldsymbol{\beta}}} \\
\frac{\partial^{2} l}{\partial \hat{\tau} \partial \hat{\gamma}} & \frac{\partial^{2} l}{\partial \hat{\tau}^{2}} & \frac{\partial^{2} l}{\partial \hat{\tau} \partial \hat{\boldsymbol{\beta}}} \\
\frac{\partial^{2} l}{\partial \hat{\boldsymbol{\beta}} \partial \hat{\gamma}} & \frac{\partial^{2} l}{\partial \hat{\boldsymbol{\beta}} \partial \hat{\tau}} & \frac{\partial^{2} l}{\partial \hat{\boldsymbol{\beta}} \partial \hat{\boldsymbol{\beta}}}
\end{array}\right] \\
& \text { Sehingga } \mathbf{I}\left(\hat{\boldsymbol{\theta}}_{(m)}\right)=-E\left[\begin{array}{ccc}
\frac{\partial^{2} l}{\partial \hat{\gamma}^{2}} & \frac{\partial^{2} l}{\partial \partial \partial \hat{\tau}} & \frac{\partial^{2} l}{\partial \hat{\gamma} \partial \hat{\boldsymbol{\beta}}} \\
\frac{\partial^{2} l}{\partial \hat{\tau} \partial \hat{\gamma}} & \frac{\partial^{2} l}{\partial \hat{\tau}^{2}} & \frac{\partial^{2} l}{\partial \hat{\tau} \partial \hat{\boldsymbol{\beta}}} \\
\frac{\partial^{2} l}{\partial \hat{\boldsymbol{\beta}} \partial \hat{\gamma}} & \frac{\partial^{2} l}{\partial \hat{\boldsymbol{\beta}} \partial \hat{\tau}} & \frac{\partial^{2} l}{\partial \hat{\boldsymbol{\beta}} \partial \hat{\boldsymbol{\beta}}}
\end{array}\right]
\end{aligned}
$$

Matriks hessian berisi turunan kedua dari fungsi likelihood terhadap parameter $\boldsymbol{\beta}, \tau$, dan $\gamma$. Langkah-langkah Fisher Scoring Algorithm sebagai berikut :

1. Menentukan vektor awal parameter $\boldsymbol{\theta}_{\mathbf{0}}$ dengan mengasumsikan data memenuhi model regresi linier berganda:

$\mathbf{Y}^{*}=\beta_{0(0)}+x_{i 1} \beta_{1_{(0)}}+\ldots+x_{i p} \beta_{p_{(0)}}+\varepsilon_{i}$ dimana $i=1,2, \ldots, n$ dan dengan metode kuadrat terkecil diperoleh

$$
\widehat{\boldsymbol{\beta}}_{(0)}=\left(\mathbf{X}^{T} \mathbf{X}\right)^{-1} \mathbf{X}^{T} \mathbf{Y}^{*}
$$

2. Membentuk vektor gradien $\mathbf{D}(\widehat{\boldsymbol{\theta}})$.

3. Membentuk matriks hessian $\mathbf{H}\left(\hat{\boldsymbol{\theta}}_{(0)}\right)$.

4. Membentuk matriks informasi Fisher $\mathbf{I}\left(\hat{\boldsymbol{\theta}}_{(0)}\right)$.

5. Memasukkan nilai $\widehat{\boldsymbol{\theta}}_{(0)}$ sehingga diperoleh vektor gradien $\mathbf{D}\left(\hat{\boldsymbol{\theta}}_{(0)}\right)$ dan matriks hessian $\mathbf{H}\left(\hat{\boldsymbol{\theta}}_{(0)}\right)$.

6. Mulai dari $m=0$ dilakukan iterasi pada $\widehat{\boldsymbol{\theta}}_{(r+1)}=\hat{\boldsymbol{\theta}}_{(r)}+\mathbf{I}^{-1}\left(\hat{\boldsymbol{\theta}}_{(\mathrm{m})}\right) \mathbf{D}\left(\hat{\boldsymbol{\theta}}_{(\mathrm{m})}\right)$, nilai $\hat{\boldsymbol{\theta}}_{(\mathrm{m})}$ merupakan sekumpulan penaksir parameter yang konvergen saat iterasi ke- $m$.

7. Jika belum diperoleh penaksiran parameter yang konvergen saat iterasi ke- $m$, maka dilanjutkan kembali ke langkah 5 hingga iterasi ke- $m+1$. Iterasi akan berhenti apabila nilai dari $\left\|\hat{\boldsymbol{\theta}}_{(m+1)}-\hat{\boldsymbol{\theta}}_{(\mathrm{m})}\right\| \leq \varepsilon$ dan $\quad \varepsilon>0$ adalah bilangan yang sangat kecil.

Fisher Scoring Algorithm digunakan di dalam algoritma yang digunakan dalam Package Gamlss pada software Rstudio yaitu algoritma Rigby Stasinopoulos (RS Algorithm). RS Algorithm merupakan generalisasi dari algoritma yang digunakan Rigby dan Stasinopoulos (1996) dalam melakukan fitting terhadap Mean and Dispersion Addative Models (MADAM).

\section{G. Pengujian Parameter}

Pengujian hipotesis secara serentak pada parameter model ZIPIGR dilakukan dengan menggunakan metode Maximum Likelihood Ratio Test (MLRT). Pengujian hipotesis secara serentak yaitu sebagai berikut.

Hipotesis :

$\mathrm{H}_{0}: \beta_{1}=\beta_{2}=\ldots=\beta_{k}=0$

$\mathrm{H}_{1}$ : minimal ada satu $\beta_{j} \neq 0$, dengan $j=1,2, \ldots, k$

Statistik uji :

$$
G^{2}=2[\ln L(\hat{\Omega})-\ln L(\hat{\omega})]
$$

Keputusan yang didapatkan akan Tolak $\mathrm{H}_{0}$ jika $G^{2}>\chi_{(\alpha, v)}^{2}$, dengan $\mathrm{v}$ adalah pengurangan antara banyaknya parameter di bawah populasi dengan banyaknya parameter di bawah $\mathrm{H}_{0}$.

Pengujian parsial pada ZIPIGR memiliki hipotesis sebagai berikut :

- Parameter $\beta$

Hipotesis :

$\mathrm{H}_{0}: \beta_{j}=0$

$\mathrm{H}_{1}: \beta_{j} \neq 0$ dengan $j=1,2, \ldots, k$

- Parameter $\tau$

Hipotesis :

$\mathrm{H}_{0}: \tau=0$

$\mathrm{H}_{1}: \tau \neq 0$

- Parameter $\gamma$

Hipotesis :

$\mathrm{H}_{0}: \gamma=1$

$\mathrm{H}_{1}: \gamma \neq 1$

Statistik uji :

$$
Z=\frac{\hat{\theta}_{j}}{s e\left(\hat{\theta}_{j}\right)}
$$

dimana se $\left(\hat{\theta}_{j}\right)$ merupakan standar eror dari dari $\hat{\theta}_{j}$, sedangkan $\theta$ merupakan parameter yang diuji. Nilai $s e\left(\hat{\theta}_{j}\right)$ didapatkan dari elemen diagonal yang bersesuaian dari invers matriks informasi Fisher yang diperoleh dari persamaan :

$\operatorname{cov}(\hat{\boldsymbol{\theta}})=-\left(\mathbf{H}^{-1}(\hat{\boldsymbol{\theta}})\right)$. Keputusan yang didapatkan akan tolak $\mathrm{H}_{0}$ jika $|Z|>Z_{(\alpha / 2)}$, dimana $\alpha$ adalah tingkat signifikansi.

\section{H. Kriteria Kebaikan Model}

Pemilihan model terbaik dilakukan untuk mendapatkan faktor yang paling mendukung penelitian. Kriteria kebaikan yang digunakan adalah Akaike's Information Criteria (AIC). 
Suatu model dikatakan baik apabila nilai AICnya paling kecil diantara semua model [10]. Besarnya AIC dapat dihitung dengan Persamaan (19).

$$
\mathrm{AIC}=-2 \log L(\hat{\boldsymbol{\theta}})+2 k
$$

dimana $L$ merupakan maksimum likelihood, $n$ merupakan jumlah unit penelitian, dan k merupakan banyaknya parameter pada model.

\section{Angka Kematian Ibu}

Angka Kematian Ibu (AKI) adalah rasio kematian ibu pada masa kehamilan, persalinan, dan nifas yang disebabkan oleh kehamilan, persalinan, dan nifas atau pengelolaannya tetapi bukan karena sebab-sebab lain seperti kecelakaan atau terjatuh di setiap 100.000 kelahiran hidup [1]. Selain disebabkan oleh kondisi ibu, AKI juga disebabkan oleh keterlambatan mengenal tanda bahaya dan pengambilan keputusan, terlambat mencapai fasilitas kesehatan, dan terlambat mendapatkan pelayanan di fasilitas kesehatan. Dimensi kematian ibu tersebut dirumuskan menjadi " 4 Terlalu, 3 Terlambat", yang berarti terlalu muda ( $<20$ tahun), terlalu tua $(>35$ tahun), terlalu banyak anak (jumlah anak lebih dari tiga), terlalu dekat jarak kelahiran ( $<2$ tahun), terlambat mencapai fasilitas kesehatan, terlambat mendapatkan pertolongan/penanganan, dan terlambat mengenali tanda bahaya kehamilan dan persalinan [11].

Masa nifas merupakan masa setelah plasenta lahir dan berakhir ketika alat-alat kandungan kembali seperti keadaan sebelum hamil. Masa nifas berlangsung kira-kira 6 minggu. Periode masa nifas dimulai dari 6 jam sampai dengan 42 hari paska melahirkan. Masa ini penting sekali untuk dipantau karena sebagian besar kematian maternal terjadi pada masa nifas. Masa nifas merupakan masa kritis baik pada ibu maupun bayi. Tahapan pada masa nifas adalah sebagai berikut [12] :

1. Periode immediate postpartum.

2. Periode early postpartum (>24 jam-1 minggu).

3. Periode late postpartum (>1 minggu- 6 minggu).

4. Remote puerperium.

\section{METODOLOGI PENELITIAN}

\section{A. Sumber Data}

Data yang digunakan dalam penelitian ini merupakan data sekunder, yang diperoleh dari Dinas Kesehatan Provinsi Jawa Tengah. Unit penelitian yang digunakan adalah sebanyak 91 kecamatan di Karesidenan Pekalongan, Provinsi Jawa Tengah tahun 2017. Karesidenan Pekalongan terdiri dari Kabupaten Pekalongan, Kota Pekalongan, Kabupaten Tegal, Kota Tegal, Batang, Brebes, dan Pemalang.

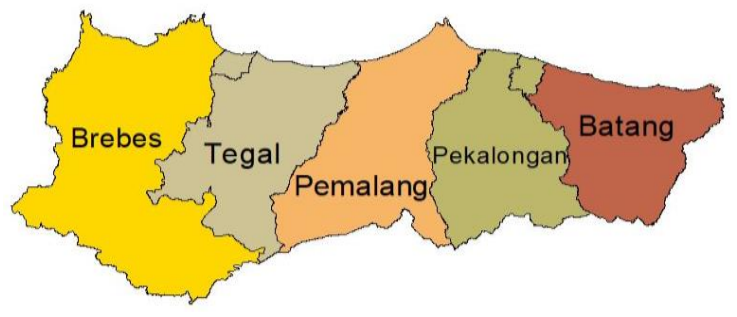

Gambar 1. Peta Karesidenan Pekalongan

\section{B. Variabel Penelitian}

Variabel-variabel yang digunakan dalam penelitian ini terdapat pada Tabel 1 .
Tabel 1.

Variabel Penelitian

\begin{tabular}{|c|c|}
\hline Variabel & Keterangan \\
\hline $\mathrm{Y}$ & Jumlah kematian ibu nifas \\
\hline $\mathrm{X}_{1}$ & Persentase ibu nifas yang mendapatkan vitamin A \\
\hline $\mathrm{X}_{2}$ & $\begin{array}{l}\text { Persentase ibu hamil yang melakukan pemeriksaan } \\
\text { kehamilan K4 }\end{array}$ \\
\hline $\mathrm{X}_{3}$ & $\begin{array}{l}\text { Persentase ibu hamil yang persalinannya di tolong } \\
\text { oleh tenaga kesehatan }\end{array}$ \\
\hline $\mathrm{X}_{4}$ & $\begin{array}{l}\text { Persentase ibu hamil yang melakukan imunisasi } \\
\text { TT2+ }\end{array}$ \\
\hline $\mathrm{X}_{5}$ & Persentase ibu hamil yang mendapatkan Fe3 \\
\hline $\mathrm{X}_{6}$ & Rasio bidan per 100.000 penduduk \\
\hline
\end{tabular}

\section{Langkah Analisis}

Langkah-langkah analisis dalam penelitian ini dituliskan sebagai berikut :

1. Melakukan analisis statistika deskriptif pada data.

2. Menghitung korelasi antar variabel respon dengan variabel prediktor.

3. Mendeteksi kasus multikolinearitas dari variabel prediktor menggunakan VIF.

4. Melakukan uji overdispersi dengan variance test.

5. Melakkan analisis data menggunakan model ZIPIGR.

1) Menentukan nilai penaksir parameter menggunakan MLE dengan beberapa kombinasi model dari beberapa variabel dengan metode stepwise.

2) Melakukan pengujian hipotesis secara serentak terhadap parameter regresi.

3) Melakukan pengujian hipotesis secara parsial terhadap parameter regresi.

4) Menentukan model terbaik dengan membandingkan nilai AIC setiap model dan nilai parameter yang signifikan.

5) Melakukan interpretasi model.

6) Menghitung probabilitas dan ketepatan klasifikasi.

6. Menarik kesimpulan dan memberikan saran.

\section{ANALISIS DAN PEMBAHASAN}

\section{A. Karakteristik Data}

Analisis statistika deskriptif digunakan sebagai informasi awal dari data. Analisis deskriptif dari data kematian ibu nifas dan variabel-variabel yang digunakan dalam penelitian ini disajikan.pada Tabel 2.

Tabel 2.

Analisis Deskriptif

\begin{tabular}{ccccc}
\hline \hline Variabel & Mean & Varians & Minimum & Maksimum \\
\hline Y & 0,67 & 0,91 & 0 & 3 \\
X1 & 98,20 & 18.51 & 77,56 & 117,19 \\
X2 & 92,74 & 50,62 & 49,51 & 100 \\
X3 & 97,75 & 16,10 & 79,59 & 100 \\
X4 & 78,22 & 506,90 & 0,64 & 100 \\
X5 & 93,18 & 50,80 & 61,17 & 100 \\
X6 & 48,15 & 246,46 & 18,14 & 100 \\
\hline \hline
\end{tabular}

Berdasarkan Tabel 2 dapat diketahui bahwa nilai varians variabel jumlah kematian ibu nifas (Y) sebesar 0,91 dan mean sebesar 0,67. Variabel persentase ibu hamil yang melakukan imunisasi $\mathrm{TT}_{2}+\left(\mathrm{X}_{4}\right)$ memiliki nilai varians terbesar jika dibandingkan dengan variabel prediktor lainnya yang digunakan yaitu sebesar 506,90. Variabel presentase ibu hamil yang persalinannya di tolong oleh tenaga kesehatan $\left(\mathrm{X}_{3}\right)$ 
memiliki nilai varians terkecil jika dibandingkan dengan variabel prediktor lainnya yang digunakan yaitu sebesar 16,10 .

\section{B. Korelasi}

Analisis korelasi digunakan untuk mengukur kekuatan hubungan antara dua variabel melalui bilangan yang disebut koefisien korelasi. Koefisien korelasi dari masing-masing variabel disajikan pada Tabel 3.

Tabel 3.

Koefisien Korelasi Variabel Respon dan Variabel Prediktor

\begin{tabular}{c|cccccc}
\hline \hline Korelasi & $\mathbf{Y}$ & $\mathbf{X}_{\mathbf{1}}$ & $\mathbf{X}_{\mathbf{2}}$ & $\mathbf{X}_{\mathbf{3}}$ & $\mathbf{X}_{\mathbf{4}}$ & $\mathbf{X}_{\mathbf{5}}$ \\
\hline $\mathbf{X}_{\mathbf{1}}$ & 0,001 & & & & & \\
$\mathbf{X}_{\mathbf{2}}$ & 0,114 & 0,239 & & & & \\
$\mathbf{X}_{\mathbf{3}}$ & 0,157 & 0,705 & 0,526 & & & \\
$\mathbf{X}_{\mathbf{4}}$ & 0,106 & 0,107 & 0,027 & 0,035 & & \\
$\mathbf{X}_{\mathbf{5}}$ & $-0,069$ & 0,283 & 0,573 & 0,32 & 0,031 & \\
$\mathbf{X}_{\mathbf{6}}$ & $-0,212$ & $-0,389$ & $-0,274$ & $-0,368$ & $-0,067$ & $-0,123$ \\
\hline \hline
\end{tabular}

Berdasarkan Tabel 3 dapat diketahui bahwa antar variabel memiliki koefisien korelasi di bawah 0,8. Koefisien korelasi yang paling rendah yaitu antara variabel jumlah kematian ibu nifas (Y) dengan variabel persentase ibu nifas yang mendapatkan vitamin $\mathrm{A}\left(\mathrm{X}_{2}\right)$, yaitu sebesar 0,001 . Koefisien korelasi yang paling tinggi yaitu antara variabel persentase ibu nifas yang mendapatkan vitamin $\mathrm{A}\left(\mathrm{X}_{2}\right)$ dengan variabel persentase ibu hamil yang persalinannya di tolong oleh tenaga kesehatan $\left(\mathrm{X}_{3}\right)$, yaitu sebesar 0,705 .

\section{Pemeriksaan Multikolinearitas}

Asumsi yang harus terpenuhi dalam pemodelan regresi ZIPIG yaitu tidak adanya kasus multikolinearitas antar variabel. Salah satu cara untuk untuk mengetahui adanya multikolinearitas yaitu dengan cara melihat nilai Variance Inflation Factor (VIF). Nilai VIF setiap variabel prediktor disajikan pada Tabel 4.

Tabel 4.

Nilai VIF Variabel Prediktor

\begin{tabular}{ccccccc}
\hline \hline Variabel & $\mathbf{X}_{\mathbf{1}}$ & $\mathbf{X}_{\mathbf{2}}$ & $\mathbf{X}_{\mathbf{3}}$ & $\mathbf{X}_{\mathbf{4}}$ & $\mathbf{X}_{\mathbf{5}}$ & $\mathbf{X}_{\mathbf{6}}$ \\
\hline VIF & 2,38 & 2,11 & 2,80 & 1,02 & 1,60 & 1,25 \\
\hline \hline
\end{tabular}

Berdasarkan Tabel 4 dapat diketahui nilai VIF dari masingmasing variabel prediktor. Variabel dikatakan terjadi multikolinearitas jika nilai VIF lebih dari 10. Nilai VIF yang disajikan pada Tabel 4 bernilai di bawah 10, sehingga dapat disimpulkan bahwa antar variabel prediktor tidak terjadi multikolinearitas.

\section{Pemeriksaan Ekuidispersi}

Hasil uji ekuidispersi yang ditunjukkan dengan nilai $\mathrm{a}=0,346$ dengan $\mathrm{p}$-value sebesar 0,002467 yang nilainya lebih tingkat signifikansi, dimana tingkat signifikansi sebesar $1 \%$. Sehingga dapat disimpulkan bahwa nilai varians tidak sama dengan nilai rata-rata. Hal ini berarti data mengalami overdispersi. Selanjutnya dilakukan perhitungan nilai variance to mean ratio (VT) yang disajikan pada Tabel 5.

Tabel 5.

Pengujian Ekuidispersi

\begin{tabular}{rrr}
\hline \hline $\mathbf{s}^{\mathbf{2}}$ & $\boldsymbol{y}$ & VT \\
\hline 0,912 & 0,67 & 122,51 \\
\hline \hline
\end{tabular}

Berdasarkan Tabel 5 dapat diketahui bahwa nilai indeks dispersi yang dapat dilihat dari nilai variance to mean ratio
(VT) melebihi nilai 1, maka dapat disimpulkan bahwa terjadi overdispersi. Sehingga pemodelan dengan regresi ZIPIG dapat dilakukan.

\section{E. Pemodelan Regresi ZIPIG}

Berdasarkan enam variabel yang digunakan dalam mencari model dengan menggunakan metode stepwise, terdapat enam kemungkinan model ZIPIG yang telah konvergen.

$$
\begin{aligned}
& \hat{\lambda}_{i}=\exp \left(\beta_{0}+\beta_{1} x_{1 i}+\beta_{2} x_{2 i}+\beta_{3} x_{3 i}+\beta_{4} x_{4 i}+\beta_{5} x_{5 i}+\beta_{6} x_{6 i}\right) \\
& \hat{\lambda}_{i}=\exp \left(\beta_{0}+\beta_{1} x_{1 i}+\beta_{3} x_{3 i}+\beta_{4} x_{4 i}+\beta_{5} x_{5 i}+\beta_{6} x_{6 i}\right) \\
& \hat{\lambda}_{i}=\exp \left(\beta_{0}+\beta_{1} x_{1 i}+\beta_{4} x_{4 i}+\beta_{5} x_{5 i}+\beta_{6} x_{6 i}\right) \\
& \hat{\lambda}_{i}=\exp \left(\beta_{0}+\beta_{1} x_{1 i}+\beta_{4} x_{4 i}+\beta_{6} x_{6 i}\right) \\
& \hat{\lambda}_{i}=\exp \left(\beta_{0}+\beta_{1} x_{1 i}+\beta_{6} x_{6 i}\right) \\
& \hat{\lambda}_{i}=\exp \left(\beta_{0}+\beta_{6} x_{6 i}\right)
\end{aligned}
$$

\begin{tabular}{|c|c|c|c|c|c|}
\hline Variabel & $\boldsymbol{\beta}_{0}$ & $\beta_{1}$ & $\boldsymbol{\beta}_{2}$ & $\boldsymbol{\beta}_{3}$ & $\beta_{4}$ \\
\hline $\mathbf{X}_{1} \mathbf{X}_{2} \mathbf{X}_{3} \mathbf{X}_{4} \mathbf{X}_{5} \mathbf{X}_{6}$ & $-28,445$ & $-0,136$ & 0,098 & 0,374 & 0,004 \\
\hline $\mathrm{X}_{1} \mathrm{X}_{3} \mathrm{X}_{4} \mathrm{X}_{5} \mathrm{X}_{6}$ & $-24,386$ & $-0,165$ & & 0,428 & 0,013 \\
\hline $\mathrm{X}_{1} \mathbf{X}_{4} \mathrm{X}_{5} \mathrm{X}_{6}$ & 3,26 & $-0,046$ & & & 0,006 \\
\hline$X_{1} X_{4} X_{6}$ & 4,735 & $-0,044$ & & & 0,005 \\
\hline $\mathbf{X}_{1} \mathbf{X}_{6}$ & 5,18 & $-0,043$ & & & \\
\hline $\mathbf{X}_{6}$ & 0,922 & & & & \\
\hline \multicolumn{6}{|c|}{$\begin{array}{c}\text { Tabel } 6 . \\
\text { (Lanjutan) } \\
\end{array}$} \\
\hline Variabel & $\beta_{5}$ & $\beta_{6}$ & $\tau$ & & Y \\
\hline$X_{1} X_{2} X_{3} X_{4} X_{5} X_{6}$ & $-0,045$ & $-0,018$ & $-0,611$ & & ,288 \\
\hline $\mathrm{X}_{1} \mathrm{X}_{3} \mathrm{X}_{4} \mathrm{X}_{5} \mathrm{X}_{6}$ & $-0,022$ & $-0,018$ & 0,376 & & 6,04 \\
\hline$X_{1} X_{4} X_{5} X_{6}$ & 0,02 & $-0,019$ & $-5,531$ & &, 32 \\
\hline$X_{1} X_{4} X_{6}$ & & $-0,013$ & $-6,074$ & &, 288 \\
\hline $\mathbf{X}_{1} \mathbf{X}_{6}$ & & $-0,016$ & 6,078 & &, 318 \\
\hline $\mathbf{X}_{6}$ & & $-0,017$ & $-5,171$ & & 421 \\
\hline
\end{tabular}

Estimasi parameter dari setiap kemungkinan model yang telah didapatkan disajikan pada Tabel 6 .

Tabel 6.

Estimasi Parameter Kemungkinan Model Regresi ZIPIG

\section{F. Pengujian Parameter Secara Serentak}

Pengujian parameter secara serentak dilakukan dengan melihat nilai statistik uji G. Nilai statistik uji $G$ akan dibandingkan dengan nilai $\chi_{(\alpha, v)}^{2}$ dengan taraf signifikansi sebesar $\alpha=0,1$. Pengujian parameter secara serentak pada setiap kemungkinan model disajikan pada Tabel 7.

Tabel 7.

Pengujian Parameter Secara Serentak

\begin{tabular}{lccc}
\hline \hline Variabel dari Model & Statistik G & $\mathcal{X}_{\left(\kappa_{5} v\right)}^{2}$ & Keputusan \\
\hline $\mathbf{X}_{\mathbf{1}} \mathbf{X}_{\mathbf{2}} \mathbf{X}_{\mathbf{3}} \mathbf{X}_{\mathbf{4}} \mathbf{X}_{\mathbf{5}} \mathbf{X}_{\mathbf{6}}$ & 209,106 & 99,880 & Tolak $\mathrm{H}_{0}$ \\
\hline $\mathbf{X}_{\mathbf{1}} \mathbf{X}_{\mathbf{3}} \mathbf{X}_{\mathbf{4}} \mathbf{X}_{\mathbf{5}} \mathbf{X}_{\mathbf{6}}$ & 206,984 & 100,980 & Tolak $\mathrm{H}_{0}$ \\
\hline $\mathbf{X}_{\mathbf{1}} \mathbf{X}_{\mathbf{4}} \mathbf{X}_{\mathbf{5}} \mathbf{X}_{\mathbf{6}}$ & 197,682 & 102,080 & Tolak $\mathrm{H}_{0}$ \\
\hline $\mathbf{X}_{\mathbf{1}} \mathbf{X}_{\mathbf{4}} \mathbf{X}_{\mathbf{6}}$ & 197,637 & 103,177 & Tolak $\mathrm{H}_{0}$ \\
\hline $\mathbf{X}_{\mathbf{1}} \mathbf{X}_{\mathbf{6}}$ & 197,837 & 104,275 & Tolak $\mathrm{H}_{0}$ \\
\hline $\mathbf{X}_{\mathbf{6}}$ & 198,465 & 105,372 & Tolak $\mathrm{H}_{0}$ \\
\hline \hline
\end{tabular}

Berdasarkan Tabel 7 dapat diketahui bahwa nilai statistik uji $\mathrm{G}$ masing-masing kemungkinan model nilainya lebih dari $\chi_{(\alpha, v)}^{2}$, maka keputusannya adalah tolak $\mathrm{H}_{0}$. Kesimpulan yang didapatkan yaitu minimal terdapat satu parameter yang berpengaruh signifikan terhadap model. 


\section{G. Pengujian Parameter Secara Parsial}

Pengujian parameter secara parsial dilakukan untuk mencari variabel prediktor yang berpengaruh signifikan terhadap model. Pengujian parameter secara parsial pada setiap kemungkinan model disajikan pada Tabel 8 .

Tabel 8.

Pengujian Parameter Secara Parsial

\begin{tabular}{cll}
\hline \hline Model & Variabel dari Model & $\begin{array}{c}\text { Parameter } \\
\text { Signifikan }\end{array}$ \\
\hline 1 & $\mathrm{X}_{1} \mathrm{X}_{2} \mathrm{X}_{3} \mathrm{X}_{4} \mathrm{X}_{5} \mathrm{X}_{6}$ & $\beta_{0} \beta_{1} \beta_{2} \beta_{3} \tau$ \\
\hline 2 & $\mathrm{X}_{1} \mathrm{X}_{3} \mathrm{X}_{4} \mathrm{X}_{5} \mathrm{X}_{6}$ & $\beta_{0} \beta_{1} \beta_{3} \tau$ \\
\hline 3 & $\mathrm{X}_{1} \mathrm{X}_{4} \mathrm{X}_{5} \mathrm{X}_{6}$ & $\beta_{6}$ \\
\hline 4 & $\mathrm{X}_{1} \mathrm{X}_{4} \mathrm{X}_{6}$ & - \\
\hline 5 & $\mathrm{X}_{1} \mathrm{X}_{6}$ & - \\
\hline 6 & $\mathrm{X}_{6}$ & $\beta_{0} \beta_{6}$ \\
\hline \hline
\end{tabular}

Berdasarkan Tabel 8 dapat diketahui bahwa terdapat dua model yang memiliki parameter dispersi yang tidak signifikan, yaitu model ke-5 dan model ke-6. Semua kemungkinan model pada Tabel 8 tidak memiliki parameter $\gamma$ yang signifikan. Kemudian dilakukan perhitungan interval konfidensi dari nilai $\gamma$ yaitu sebesar $-100<\gamma<27,92$.

\section{H. Pemilihan Model Terbaik}

Pemilihan model regresi ZIPIG terbaik dalam penelitian ini dilakkan dengan metode stepwise dengan melihat nilai Akaike Information Criterion (AIC) terkecil dan adanya parameter dispersi $(\tau)$ yang signifikan dalam model. Nilai AIC dan adanya parameter dispersi $(\tau)$ masing-masing kemungkinan model disajikan pada Tabel 9.

Tabel 9.

Nilai AIC dan $\tau$ Model Regresi ZIPIG

\begin{tabular}{clccc}
\hline \hline Model & \multicolumn{1}{c}{$\begin{array}{c}\text { Variabel dari } \\
\text { Model }\end{array}$} & AIC & $\boldsymbol{\tau}$ & P-value $\boldsymbol{\tau}$ \\
\hline 1 & $\mathrm{X}_{1} \mathrm{X}_{2} \mathrm{X}_{3} \mathrm{X}_{4} \mathrm{X}_{5} \mathrm{X}_{6}$ & 227,106 & $-0,611$ & 0,000 \\
\hline 2 & $\mathrm{X}_{1} \mathrm{X}_{3} \mathrm{X}_{4} \mathrm{X}_{5} \mathrm{X}_{6}$ & 222,984 & 0,376 & 0,000 \\
\hline 3 & $\mathrm{X}_{1} \mathrm{X}_{4} \mathrm{X}_{5} \mathrm{X}_{6}$ & 211,682 & $-5,531$ & 0,362 \\
\hline 4 & $\mathrm{X}_{1} \mathrm{X}_{4} \mathrm{X}_{6}$ & 209,637 & $-6,074$ & 0,445 \\
\hline 5 & $\mathrm{X}_{1} \mathrm{X}_{6}$ & 207,837 & 6,078 & 0,472 \\
\hline 6 & $\mathrm{X}_{6}$ & 206,465 & $-5,171$ & 0,416 \\
\hline \hline
\end{tabular}

Berdasarkan Tabel 9 dapat diketahui bahwa nilai AIC terkecil yaitu model yang hanya mengandung variabel $\mathrm{X}_{6}$, tetapi model tersebut memiliki parameter dispersi $(\tau)$ yang tidak signifkan terhadap model, sedangkan parameter dispersi merupakan parameter yang menunjukan pengaruh variabel prediktor terhadap variabel respon. Maka dari itu, dalam penelitian ini, model yang dipilih yaitu model nomor 2 dengan AIC sebesar 222,984 dan variabel yang signifikan yaitu $X_{1}$ dan $\mathrm{X}_{3}$. Hasil estimasi parameter model regresi ZIPIG disajikan pada Tabel 10.

Tabel 10.

Penaksiran Parameter Model Regresi ZIPIG

\begin{tabular}{clll}
\hline \hline Parameter & Taksiran & $\begin{array}{c}\text { Standart } \\
\text { Eror }\end{array}$ & P-value \\
\hline $\boldsymbol{\beta}_{\mathbf{0}}$ & $-24,386$ & 7,82 & $0,002^{*}$ \\
\hline $\boldsymbol{\beta}_{\mathbf{1}}$ & $-0,165$ & 0,06 & $0,007^{*}$ \\
\hline $\boldsymbol{\beta}_{3}$ & 0,428 & 0,09 & $0,000^{*}$ \\
\hline $\boldsymbol{\beta}_{4}$ & 0,013 & 0,009 & 0,171 \\
\hline $\boldsymbol{\beta}_{5}$ & $-0,022$ & 0,044 & 0,625 \\
\hline $\boldsymbol{\beta}_{6}$ & $-0,018$ & 0,017 & 0,276 \\
\hline $\boldsymbol{\tau}$ & 0,376 & 0,003 & $0,000^{*}$ \\
\hline$\gamma$ & $-36,04$ & 10482,85 & 0,997 \\
\hline \hline
\end{tabular}

Berdasarkan Tabel 10 maka model yang didapatkan yaitu sebagai berikut :

$$
\begin{aligned}
\ln \left(\bar{\lambda}_{i}\right) & =-24,386-0,165 x_{1 i}+0,428 x_{3 i}+0,013 x_{4 i} \\
& -0,022 x_{5 i}-0,018 x_{6 i}
\end{aligned}
$$

dimana $i=1,2, \ldots, 91$.

Pada model di atas, variabel yang signifikan yaitu variabel persentase ibu nifas yang mendapatkan vitamin $\mathrm{A}\left(\mathrm{X}_{1}\right)$ dan variabel persentase ibu hamil yang persalinannya di tolong oleh tenaga kesehatan $\left(\mathrm{X}_{3}\right)$, sedangkan variabel lainnya tidak signifikan di dalam model.

Makna dari model $\ln \left(\hat{\lambda}_{i}\right)$ yaitu, untuk $X_{1}$ bahwa setiap penambahan variabel persentase ibu nifas yang mendapatkan vitamin A sebesar 1\% maka akan menurunkan rata-rata kematian ibu nifas sebesar $\exp (-0,165)=0,85$ kali dengan menganggap variabel lain konstan. Dikarenakan secara teori tujuan pemberian vitamin A pada ibu nifas yaitu untuk meningkatkan kekebalan tubuh dan mempercepat pemulihan. Selanjutnya untuk $X_{3}$ bahwa setiap penambahan variabel persentase ibu hamil yang persalinannya di tolong oleh tenaga kesehatan sebesar 1\% maka akan menaikkan rata-rata kematian ibu nifas sebesar $\exp (0,428)=1,53$ kali dengan menganggap variabel lain konstan.

$\log \operatorname{it}\left(\hat{p}_{i}\right)=-1\left(-24,386-0,165 x_{1 i}+0,428 x_{3 i}+0,013 x_{4 i}-0,022 x_{5 i}\right.$

$$
\begin{aligned}
& \left.-0,018 x_{6 i}\right) \\
& =24,386+0,165 x_{1 i}-0,428 x_{3 i}-0,013 x_{4 i}+0,022 x_{5 i} \\
& +0,018 x_{6 i}
\end{aligned}
$$

dimana $i=1,2, \ldots, 91$.

Pada model $\log i t\left(\hat{p}_{i}\right)$ variabel yang signifikan yaitu variabel persentase ibu nifas yang mendapatkan vitamin A $\left(\mathrm{X}_{1}\right)$ dan variabel persentase ibu hamil yang persalinannya di tolong oleh tenaga kesehatan $\left(\mathrm{X}_{3}\right)$, sedangkan variabel lainnya tidak signifikan di dalam model.

Arti dari model $\log i t\left(\hat{p}_{i}\right)$ yaitu setiap penambahan variabel persentase ibu nifas yang mendapatkan vitamin A sebesar $1 \%$ maka akan menaikkan peluang tidak terdapat kasus kematian ibu nifas sebesar $\exp (0,165)=1,18$ kali jika dibandingkan dengan adanya kasus kematian ibu nifas dengan menganggap variabel lain konstan. Selanjutnya untuk $\mathrm{X}_{3}$ bahwa setiap penambahan variabel persentase ibu hamil yang persalinannya di tolong oleh tenaga kesehatan sebesar 1\% maka akan menurunkan peluang tidak terdapat kasus kematian ibu nifas sebesar $\exp (-0,428)=0,65$ kali jika dibandingkan dengan adanya kasus kematian ibu nifas dengan menganggap variabel lain konstan.

\section{Probabilitas Jumlah Kematian Ibu Nifas}

Setelah didapatkan model, maka selanjutnya dihitung nilai probabilitas dengan $\log i t\left(\hat{p}_{i}\right)$ untuk setiap kecamatan di Karesidenan Pekalongan.

$\log i t\left(\hat{p}_{i}\right)=-1\left(-24,386-0,165 x_{1 i}+0,428 x_{3 i}+0,013 x_{4 i}-0,022 x_{5 i}\right.$

$$
\begin{aligned}
& \left.-0,018 x_{6 i}\right) \\
& =24,386+0,165 x_{1 i}-0,428 x_{3 i}-0,013 x_{4 i}+0,022 x_{5 i} \\
& +0,018 x_{6 i}
\end{aligned}
$$

Misalkan

$$
\begin{aligned}
a= & 24,386+0,165 x_{1 i}-0,428 x_{3 i}-0,013 x_{4 i} \\
& +0,022 x_{5 i}+0,018 x_{6 i}
\end{aligned}
$$




$$
\begin{gathered}
\widehat{p}=\frac{\exp (a)}{1+\exp (a)} \\
(1-\hat{p})=\frac{1}{1+\exp (a)}
\end{gathered}
$$

Berdasarkan model tersebut di atas, maka selanjutnya dilakukan perhitungan probabilitas jumlah kematian ibu nifas dari masing-masing kecamatan. Apabila peluang $\left(\hat{p}_{i}\right)$ yang didapatkan bernilai >0,5 maka variabel respon diklasifikasikan bernilai nol, sedangkan apabila peluang $\left(\hat{p}_{i}\right)$ yang bernilai $<0,5$ maka variabel respon diklasifikasikan bernilai $>0$. Hasil klasifikasi yang bernilai nol berjumlah 58 dengan persentase klasifikasi sebesar $63,74 \%$, sedangkan pada data asli memiliki nilai nol sebanyak 55 dengan persentase sebesar 60,44\%. Ketepatan klasifikasi yang dihasilkan disajikan pada Tabel 4.11 berikut.

Tabel 11. Ketepatan Klasifikasi

\begin{tabular}{c|cc}
\multicolumn{3}{c}{ Ketepatan Klasifikasi } \\
\hline \hline Klasifikasi & $\mathbf{0}$ & $\mathbf{> 0}$ \\
\hline $\mathbf{0}$ & 42 & 16 \\
To & 13 & 20 \\
\hline \hline Total & 55 & 36 \\
\hline
\end{tabular}

Berdasarkan Tabel 11 dapat diketahui jumlah kecamatan yang memiliki klasifikasi yang tepat yaitu sebanyak 62 kecamatan atau sebesar $68,13 \%$. Hal ini berarti meskipun persentase jumlah nilai nol hasil klasifikasi mendekati persentase data asli atau sebesar $63,74 \%$, namun ketepatan klasifikasi yang dihasilkan hanya sebesar $68,13 \%$.

\section{KESIMPULAN DAN SARAN}

Berdasarkan hasil analisis dan pembahasan didapatkan kesimpulan bahwa Model yang didapatkan yaitu sebagai berikut :

$$
\begin{aligned}
\ln \left(\hat{\lambda}_{i}\right) & =-24,386-0,165 x_{1 i}+0,428 x_{3 i}+0,013 x_{4 i} \\
& -0,022 x_{5 i}-0,018 x_{6 i}
\end{aligned}
$$

dan

$$
\begin{aligned}
\log i t\left(\hat{p}_{i}\right) & =-1\left(-24,386-0,165 x_{1 i}+0,428 x_{3 i}+0,013 x_{4 i}-0,022 x_{5 i}\right. \\
& \left.-0,018 x_{6 i}\right) \\
& =24,386+0,165 x_{1 i}-0,428 x_{3 i}-0,013 x_{4 i}+0,022 x_{5 i} \\
& +0,018 x_{6 i}
\end{aligned}
$$

Berdasarkan model regresi ZIPIG yang terbentuk, didapatkan bahwa faktor-faktor yang berpengaruh signifkan terhadap jumlah kematian ibu nifas yaitu persentase ibu nifas yang mendapatkan vitamin $\mathrm{A}\left(\mathrm{X}_{1}\right)$ dan persentase persalinan ibu hamil yang persalinannya ditolong oleh tenaga kesehatan $\left(\mathrm{X}_{3}\right)$.

Saran untuk Dinas Kesehatan setiap kabupaten/kota di Karesidenan Pekalongan yaitu apabila terdapat ibu hamil/bersalin/nifas yang melakukan pemeriksaan sebaiknya proses pencatatan data pemeriksaan dibedakan berdasarkan kecamatan asal, agar tidak terdapat data yang memiliki persentase melebihi $100 \%$ dan sebaiknya memperhatikan variabel yang memiliki tanda koefisien yang negatif pada model yang telah di dapatkan untuk menekan kasus kematian ibu nifas. Selain itu, sebaiknya Dinas Kesehatan di Karesidenan Pekalongan sebaiknya memastikan bahwa tenaga kesehatan yang menolong persalinan senantiasa menjaga kesterilan peralatan yang digunakan agar kesehatan ibu yang melahirkan tetap terjaga kesehatannya serta melakukan sosialisasi kepada ibu hamil tentang pengetahuan mengenai kesehatan ibu dan bayi mulai proses kehamilan hingga masa nifas. Saran untuk penelitian selanjutnya yaitu sebaiknya menggunakan syntax pemrograman yang dapat memperoleh nilai parameter zero-inflated $(\gamma)$ di setiap variabel serta menggunakan variabel prediktor yang sesuai dengan kerangka konsep determinan kematian ibu dari McCharthy dan Maine untuk mengetahui variabel-variabel signifikan yang lainnya serta mencoba menggunakan variabel exposure.

\section{DAFTAR PUSTAKA}

[1] Kementerian Kesehatan Indonesia, Profil Kesehatan Indonesia Tahun 2018, Jakarta: Kementerian Kesehatan Indonesia, 2019.

[2] Dinas Kesehatan Jawa Tengah, Profil Kesehatan Provinsi Jawa Tengah Tahun 2018, Semarang: Dinas Kesehatan Provinsi Jawa Tengah, 2019.

[3] Badan Pusat Statistik, Profil Penduduk Indonesia Hasil Supas 2015, Jakarta: Badan Pusat Statistik, 2016.

[4] ASEAN, ASEAN Statistical Report on Millennium Development Goals 2017, Jakarta: Eu-Compass Project, 2017.

[5] Dinas Kesehatan Prov. Jateng, Profil Kesehatan Provinsi Jawa Tengah Tahun 2017, Semarang: Badan Pusat Statistik Provinsi Jawa Tengah, 2018.

[6] R. E. Walpole, Pengantar Statistika, 3nd ed., Jakarta: Gramedia Pustaka Utama, 1992.

[7] D. E. Gujarati, Basic Econometrics, 4th ed., New York: McGraw-HiII, 2003.

[8] J. Hilbe, Negative Binomial Regression, 1st ed., New York: Cambridge University Press, 2007.

[9] D. Karlis and E. Xekalaki, "A Simulation Comparison of Several Procedures for Testing the Poisson Assumption," Journal of the Royal Statistical Society, vol. 49, pp. 355-382, 2000.

[10] H. Akaike, "A Bayesian Analysis of The Minimum AIC Procedure," Annals of Statistical Mathematics, pp. 9-14, 1978.

[11] Dinkes Jateng, Profil Kesehatan Provinsi Jawa Tengah Tahun 2018, Semarang: Dinas Kesehatan Provinsi Jawa Tengah, 2019.

[12] E. D. Wahyuni, Asuhan Kebidanan Nifas dan Menyusui, Jakarta Selatan: Pusdik SDM Kesehatan, 2018. 